\title{
Preparation and quality evaluation of carbonated guava fruit drinks produced from BARI Payera-4
}

\author{
Md. Abdul Wazeda,b,", Mohim Das Guptaa, Shamor kanti Deya, Rahul Kumar Majumdera, Al Amina, Shabadur \\ Rashid Shakiba \\ aDepartment of Food Science and Engineering, German University Bangladesh (GUB), Gazipur-1702, Bangladesh \\ bDepartment of Food Engineering and Technology, Hajee Mohammad Danesh Science and Technology University (HSTU), Dinajpur-5200, Bangladesh \\ *Corresponding Author Email: hredoyfpe@gmail.com
}

\section{Doi: 10.2478/mjhr-2021-0011}

\begin{abstract}
:
The present study was conducted with the objective of utilizing new varieties of guava (BAARI Payera-4) fruit in the production of carbonated drinks and also evaluation of different properties such as physico-chemical and sensory characteristics with respect to the different guava juice concentrations $(10 \%$, $15 \%$, and $20 \%$ of juice) and TSS $\left(10^{\circ}, 12^{\circ}\right.$ and $15^{\circ}$ Brix), respectively. This variety is selected for the preparation of carbonated fruit drinks because of its refreshing acidic taste, seedless with good keeping quality and also delicious fruit with good aroma. The extracted fruit juice subjected to carbonation. The physicochemical factors such as viscosity, TSS, acidity, $\mathrm{pH}$, color, ascorbic acid, volume of $\mathrm{CO}_{2}$ and sugars were studied and the changes were observed. The sensory evaluation study was done with hedonic scale to find the best combination of juice concentration and TSS. The obtained results of physiochemical parameters showed that guava juice level at $20 \%$ with $12^{\circ} \mathrm{Bx}$ (Sample T6) had received highest ascorbic acid $28.87 \mathrm{mg} / 100 \mathrm{~g}$, high acidity $0.51 \%$, high color value $\mathrm{EE} 4.60$ and highest volume of $\mathrm{CO}_{2}$. Data also revealed that sample $\mathrm{T} 6$ found to be superior among all with respect to sensory qualities such as color, flavor, appearance, taste and overall acceptability. In conclusion, the overall assessment pointed that the resulting carbonated drinks developed from BARI Payera-4, sample T6 was best for all physicochemical characteristics and, in general, resulted in good sensory behavior, indicating that it could be a promising alternative to synthetic soft drinks.
\end{abstract}

Keywords: Carbonated drinks, Physico-chemical characteristics, Sensory evaluation, BARI Payera-4.

\subsection{Introduction}

Fruits and Vegetables both fresh and processed are imperative in improving the nutritional quality of our daily life. Guava (Psidium guajava L.) belongs to the family Myrtaceae, consumed as fresh fruit [1] which is highly perishable when kept at ambient temperature and not stored for longer use [2]. Under these conditions guava growers fail to get attractive return and a lot of produce goes as waste. Therefore, necessary steps have to be taken to develop advanced technologies for processing and preservation of such enormous produce. Besides, this fruit contains a high level of vitamin $\mathrm{C}$ and lycopene compared to orange fruit [3]. In addition it is also rich in vitamin A, omega-3 and -6 polyunsaturated fatty acids, dietary fibre, pectin, sugars, certain minerals and antioxidant pigments such as carotenoids and polyphenols $[1,3]$. Due to its high potential in a health-promoting capacity, researchers and producers have made various explorations with regards to utilizing this fruit for the development of different food products [4].

The guava variety, BAARI Peyara-4 developed by Bangladesh Agriculture Research Institute (BARI), Gazipur, Bangladesh year of release 2017. Regular bearer fruit oblong shape, seedless with good keeping quality, late harvesting season (September-October). Unlike other varieties, BARI Payera-4 is delicious fruit with good aroma and has a refreshing acidic taste. It contain 9.5-10\% TSS [5].

Guava fruits are processed in various products like nectar, pulp, jam, jelly, fruit bars, juice and dehydrated products [1]. Among these products, the carbonated guava juice becomes economically important in the market due to its natural flavor, high in nutritional values and used as an alternative to other beverages such as soft drinks, tea and coffee [6]. In Bangladesh, the cold drinks are in demand for the great part of the year, so there is a need for carbonated drinks with increased nutritional value [7]. In the present study, carbonation was done to improve the nutritional value of the aerated drink and improve the economic value of guava fruit as well as improve the economic status of farmers and processors [8].

Carbonation is the practice in which carbonated water was made by passing pressurized carbon dioxide through water [9]. In this process, the pressure increases the solubility and allows more carbon dioxide to dissolve than would be possible under standard atmospheric pressure. When the bottle was opened, the pressure is released allowing the gas to come out of the solution, thus forming the characteristic bubbles [10]. Carbonation process has gained its popularity for its pleasurable taste and is a significant factor of sparkling drinks [11] which also improve the flavor as well as make available refreshing sensation to carbonation [12]. Fruit juice is a drink that is made from fruit material either with or without any additional ingredient. It is a refreshing liquid and the raw material usually contains minor ingredients, particularly vitamins and minerals [13]. An alternative to the carbonated soft drink is the fruit juice which contains water, sweetening agent and flavors. The most popular beverage in the world is tea and the next position is occupied by bottled water and soft drinks [14]. This trend has been set by major soft drink producing companies which adjusted its products with consumer lifestyles, high marketing budgets and sophisticated distribution systems. The formulation of carbonated fruit beverage offers variety of flavors, nutrients, long shelf life and other physiological benefits with a greater margin of safety in drink with a lower inherent cost in comparison with the fruit juice. Therefore, the aim of the present study was to prepare carbonated guava drink using the new variety of guava. Furthermore, to evaluate the physico-chemical and sensory parameters of the prepared drink so that they can be further standardized and used commercially.

\subsection{Methods and material}

\subsection{Sample collection}

Ripened guavas (BARI Payera-4) with 80-90\% maturity and free from visual blemishes and bruises were collected from Bangladesh Agriculture Research Institute (BARI), Gazipur, Bangladesh. The guava fruits were sorted based on maturity and quality before processing. The proposed research was carried out in the department of Food Science and Engineering, German University Bangladesh, Gazipur, Bangladesh.

\subsection{Guava juice preparation}

Guava juice was prepared as per the procedure outlined by Hossen et al. [15]. Healthy guavas were washed in water and cut the fruit into pieces blended the fruit into pulp using kitchen blender, water, sugar, citric acid $(2.2 \mathrm{~g} / \mathrm{L}$ ) and preservative (sodium benzoate- $2 \mathrm{~g} / \mathrm{L}$ ) were added. Sugar was added to attain the required TSS. Pasteurization was done at $85^{\circ} \mathrm{C}$ for $2-3$ minutes and cooled at room temperature $25 \pm 2{ }^{\circ} \mathrm{C}$ [16]. For the improvement of nutritional profile with increased percent of guava fruit juice from 10,15 and $20 \%$ with lower sugar concentration of 10,12 and $15^{\circ}$ Brix, respectively. The detailed treatment for standardization of carbonated guava drink is presented in the following Table 1. 
Table 1: Various combination of guava juice and sugar concentrations in carbonated guava drink.

\begin{tabular}{cl}
\hline Treatments & Guava juice and sugar concentrations \\
\hline T1 & $10 \%$ Guava fruit juice $+10^{\circ}$ Brix \\
T2 & $15 \%$ Guava fruit juice $+10^{\circ}$ Brix \\
T3 & $20 \%$ Guava fruit juice $+10^{\circ}$ Brix \\
T4 & $10 \%$ Guava fruit juice $+12^{\circ}$ Brix \\
T5 & $15 \%$ Guava fruit juice $+12^{\circ} \mathrm{Brix}$ \\
T6 & $20 \%$ Guava fruit juice $+12^{\circ} \mathrm{Brix}$ \\
T7 & $10 \%$ Guava fruit juice $+15^{\circ}$ Brix \\
T8 & $15 \%$ Guava fruit juice $+15^{\circ}$ Brix \\
T9 & $20 \%$ Guava fruit juice $+15^{\circ}$ Brix \\
\hline
\end{tabular}

\subsection{Carbonation}

After cooling, the pasteurized guava drink was subjected to carbonation. The prepared guava drink was filled in $250 \mathrm{ml}$ PET bottles at the pressure range of 100 psi by using carbonation unit. After carbonation the bottles were sealed tightly by using capping machine and it is stored at cool and ambient temperature for further studies. The carbonated guava drink was prepared as shown in figure 1.

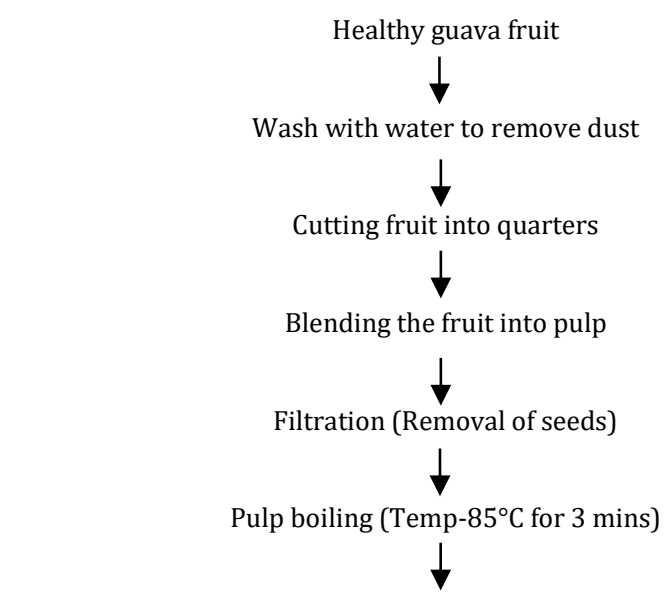

Adding water, citric acid (2.2g/L), preservative (sodium benzoate: $2 \mathrm{~g} / \mathrm{L}$ )

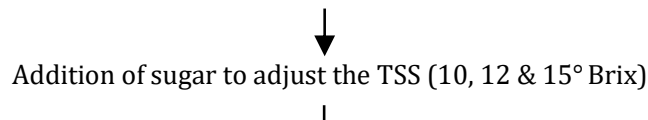

Pasteurization at $80^{\circ} \mathrm{C}$ for $2-3$ minutes

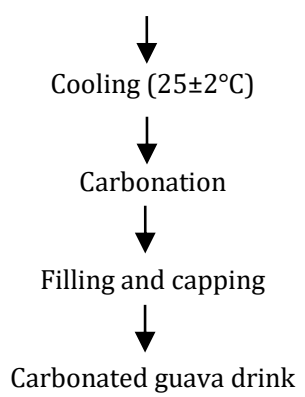

Figure 1: Process flow diagram for carbonated guava drink

\subsection{Measurement of physico-chemical properties}

\subsubsection{Viscosity}

The viscosity is a crucial parameter for judging the consistency of the prepared guava fruit drinks [17]. The viscosity was measured by a Brookfield viscometer equipped with a spindle no.0.2 at $100 \mathrm{rpm}$ [18]. Each $200 \mathrm{ml}$ sample was prepared in a $250 \mathrm{ml}$-beaker and the measurement was made at room temperature $\left(28 \pm 2^{\circ} \mathrm{C}\right)$.

\subsection{2. $\mathrm{pH}$}

The $\mathrm{pH}$ value was measured using digital $\mathrm{pH}$ meter [19].

\subsubsection{Acidity (\%)}

Acidity (\%) was estimated using standard AOAC method, $50 \mathrm{ml}$ of distilled water was added to $10 \mathrm{ml}$ fruit drink sample. 3-4 drops of phenolphthalein indicator was added. It was titrated against $0.1 \mathrm{~N}$ sodium hydroxide. The predominant acid in guava is citric acid. The percentage acidity was calculated using the following formula [20].

$$
\% \text { Acidity }=\frac{\text { Titre value } \times \text { Equivalent weight of acid } \times 100}{\text { Volume of sample taken } \times 1000}
$$

\subsubsection{Total soluble solid (TSS)}

The guava drink was measured for TSS by an Abbe digital refractometer (Shanghai Precision \& Scientific Instrument Co., Shanghai, China) at room temperature $\left(28 \pm 2^{\circ} \mathrm{C}\right)[7]$. One or two drops of juice were placed on the hand refractometer for TSS measurement. It was expressed in degree Brix $\left({ }^{\circ} \mathrm{Bx}\right)$.

\subsubsection{Ascorbic acid}

Drink sample was determined for ascorbic acid by titration with a 2,6 dichlorophenolindophenol sodium salt solution as reported in AOAC [21]. 


\subsubsection{Sugars}

The total sugar, reducing and non-reducing sugar was determined by Ranganna [22]

\subsubsection{Color}

Hunter lab color flex meter (Hunter Associates Laboratory, Inc. Reston, Virgina, USA) was used for the measurement of color of guava drink [23]

\subsection{8. $\mathrm{CO}_{2}$ analysis}

$\mathrm{CO}_{2}$ analysis was done using $\mathrm{CO}_{2}$ analyzer [24]. Where $\mathrm{CO}_{2}$ analyzer consist of 2 probes where probe 1 is used for measuring $\mathrm{CO}_{2}$ and temperature measurement probe 2 is used to measure the humidity and dew point where the samples stored in PET bottles were exposed to the probe the digital meter in the $\mathrm{CO}_{2}$ analyzer automatically detects the $\%$ of dissolved $\mathrm{CO}_{2}$ in the head space.

\subsection{Sensory Evaluation}

Organoleptic evaluation of carbonated guava drinks for color, flavor, taste, appearance and overall acceptability was carried out by using standard method of Thongrote et al. [25]. For these 20 judges were used and 1 to 9-point hedonic scale was used for rating the quality. The mean of ten judges was considered for evaluating the quality.

\subsection{Statistical analysis}

All of the experimental determinations were carried out in triplicate. The statistical analysis was performed with SPSS 16.0 software, using analysis of variance (ANOVA) and Duncan' Multiple Range Test (DMRT) with a 95\% confidence level $(\mathrm{p}<0.05)$

\subsection{Results and Discussion}

The carbonated guava drink was processed at $0^{\circ} \mathrm{C}$ temperature in the pressure range of $100 \mathrm{psi}$ with increased level of juice concentration varies from $10 \%$, $15 \%$ and $20 \%$ and TSS ranged from $10^{\circ}, 12^{\circ}$ and $15^{\circ} \mathrm{Bx}$, respectively. The physico-chemical properties and sensory attributes with various combinations of fruit juice and total soluble solid via T1, T2, T3, T4, T5, T6, T7, T8 and T9, respectively were studied.

\subsection{Effect of guava juice and sugar concentration in carbonated fruit drink on physico-chemical parameters}

Data pertaining to various physico-chemical parameters of carbonated guava drink viz. $\mathrm{pH}$, TSS, acidity, viscosity, color, reducing sugar, non-reducing sugar and total sugar were evaluated and results obtained are given in table 2.

Table 2: Physico-chemical parameters of carbonated guava drink in various concentrations of fruit juice (10, 15 and $20 \%)$ and $\mathrm{TSS}\left(10,12\right.$ and $\left.15^{\circ} \mathrm{Bx}\right)$

\begin{tabular}{|c|c|c|c|c|c|c|c|c|c|}
\hline $\begin{array}{c}\text { Juice } \\
+ \\
\text { TSS Concentration }\end{array}$ & $\begin{array}{l}\text { Viscosity } \\
\text { (cp) }\end{array}$ & $\mathrm{pH}$ & $\begin{array}{c}\text { TSS } \\
\left({ }^{\circ} \mathrm{Bx}\right)\end{array}$ & $\begin{array}{c}\text { Acidity } \\
(\%)\end{array}$ & $\begin{array}{l}\text { Color } \\
(\Delta E)\end{array}$ & $\begin{array}{l}\text { Volume of } \\
\mathrm{CO}_{2} \\
(\%)\end{array}$ & $\begin{array}{l}\text { Reducing } \\
\text { sugar } \\
(\%)\end{array}$ & $\begin{array}{l}\text { Non- } \\
\text { reducing } \\
\text { sugar } \\
(\%)\end{array}$ & $\begin{array}{c}\text { Total sugar } \\
(\%)\end{array}$ \\
\hline $\mathrm{T} 1$ & 29.1 & 3.98 & 10.7 & 0.46 & 3.08 & 2.5 & 2.90 & 1.63 & 13.1 \\
\hline $\mathrm{T} 2$ & 29.3 & 4.37 & 12.1 & 0.39 & 2.61 & 2.3 & 2.44 & 1.38 & 14.3 \\
\hline T3 & 29.4 & 4.62 & 13.7 & 0.33 & 1.15 & 2.0 & 3.99 & 1.73 & 13.7 \\
\hline $\mathrm{T} 4$ & 29.5 & 4.19 & 14.9 & 0.43 & 4.07 & 2.5 & 2.45 & 1.48 & 13.3 \\
\hline T5 & 29.7 & 4.53 & 15.2 & 0.36 & 2.09 & 2.3 & 2.12 & 1.65 & 13.9 \\
\hline T6 & 28.9 & 3.87 & 16.8 & 0.51 & 4.60 & 2.7 & 4.84 & 1.89 & 15.1 \\
\hline $\mathrm{T} 7$ & 29.9 & 4.71 & 15.8 & 0.31 & 1.51 & 2.3 & 4.32 & 1.56 & 14.1 \\
\hline T8 & 29.5 & 3.93 & 16.5 & 0.47 & 4.07 & 2.5 & 2.32 & 1.55 & 13.7 \\
\hline T9 & 29.1 & 4.07 & 16.7 & 0.45 & 2.10 & 2.7 & 4.90 & 1.95 & 14.1 \\
\hline
\end{tabular}

\section{Total soluble solids (TSS)}

Total soluble solids can be defined as the amount of sugar and soluble mineral salts present in the fruit juice [26]. The experimental result showed that, the TSS content varied from 10.7 to $16.8^{\circ}$ brix. The result was also observed that among the treatment the TSS was high in combination of guava juice at $20 \%$ with TSS at $12^{\circ} \mathrm{Bx}$ (T6). The probable reasons for increase in TSS can be the conversion of organic acids to sugars through gluconeogenesis [26]. The present findings are in close conformity with the findings of Deka et al. [27]. Similar findings were also reported by Sharma and Singh [28].

\section{Titrable acidity}

Titrable Acidity of product is the acidity in terms of the predominant acid present in the juice i.e. citric acid [29]. The acidity of any food product (as \% Anhydrous Citric Acid) is the first preference of a consumer for acceptance, and it is considered to be a dependent attribute of the fruit drinks [17]. It is also responsible for defining the shelf life of the product [30]. Titrable acidity was low for combination of guava juice at $10 \%$ with TSS at $15^{\circ} \mathrm{Bx}$ (T7) and high for combination of guava juice at $20 \%$ with TSS at $12^{\circ} \mathrm{Bx}$ (T6). The decrease in acidity may be attributed to conversion of acids into salts and sugars. Similar result was found by Tiwari [31] in guava and papaya blended RTS beverage and Dhaliwal and Hira [32] in carrot juice blends. The increase in acidity of guava drink might be due to formation of organic acids by ascorbic acid degradation. It is also due to formation of acids from sugar [33].

\section{pH}

$\mathrm{pH}$ was low in in combination of guava juice at $20 \%$ with TSS at $12^{\circ} \mathrm{Bx}$ (T6). The reason for decrease in pH might be due to increase in titrable acidity, as acidity and $\mathrm{pH}$ are inversely proportional to each other [34]. This gradual decrease in $\mathrm{pH}$ has a significant effect as lower pH does not allow pathogenic microorganisms to grow and hence acts as a preservative. Thus, lower $\mathrm{pH}$ indicates long stability of drinks. It also affects the organoleptic quality of juice [34]. Del C. et al. [35] also found a pH increase in citrus segments and juices stored at $4^{\circ} \mathrm{C}$

\section{The viscosity}

Guava drink viscosity has been considered as an important quality parameter related to the juice filtration or pressing, namely a relative low viscosity leads to a better filtration [36]. The viscosity was high in case of combination of guava juice at $10 \%$ with TSS at $15^{\circ} \mathrm{Bx}$ (T7) sample and low for combination of guava juice at $20 \%$ with TSS at $12^{\circ} \mathrm{Bx}(\mathrm{T} 6)$. The viscosity of guava fruit carbonated drinks increased sharply, mainly due to the increase in the concentration of soluble substances [37]

\section{Color}

The color value was high for combination of guava juice at $20 \%$ with TSS at $12^{\circ} \mathrm{Bx}$ (T6) samples and low for combination of guava juice at $20 \%$ with TSS at $10^{\circ} \mathrm{Bx}$ (T3) samples. The rapid color change in samples could be due to the effect of temperature during processing [38] and also might be due to browning of the juice [39].

\section{Sugars}

Data pertaining to effect of fruit juice concentration and its TSS on reducing sugar, non-reducing sugar and total sugars of carbonated guava fruit drinks are presented in table 2 . 


\section{Reducing sugar}

Data from table 2 revealed that the reducing sugar content were ranged from 2.12 to 4.90 percent and varied significantly with respect juice concentration and its TSS. The increase in reducing sugar may be attributed due to gradual inversion of non-reducing sugars to reducing sugar by the hydrolysis process. These results are in close conformity with the findings of Brekke et al. [40] and Tiwari [31].

\section{Non-reducing sugar}

The negligible deviation was observed in case of non-reducing sugar content and was varied from 1.38 to 1.95 percent. The highest non reducing sugar level (1.95\%) was observed at $20 \%$ guava juice with TSS at $15^{\circ} \mathrm{Bx}(\mathrm{T} 9)$.

\section{Total Sugar}

Total sugar significantly $(\mathrm{p}<0.05)$ differed between the treatments as given in Table 2 . The highest mean value of $15.1 \%$ was obtained in the sample $\mathrm{T} 6$. Therefore, the increase in total sugars might be due to the hydrolysis of polysaccharides and its conversion into simple sugars [33].

\section{Volume of $\mathrm{CO}_{2}$}

Volume of $\mathrm{CO}_{2}$ released from the sample combination of guava juice at $20 \%$ with TSS at $12^{\circ} \mathrm{Bx}$ (T6) and combination of guava juice at $20 \%$ with TSS at $15^{\circ} \mathrm{Bx}$ (T9) has highest level of $2.7 \%$

\section{Ascorbic acid}

Ascorbic acid (vitamin-C) is considered to be a heat-labile vitamin and most sensitive towards light and higher temperature [17]. Fig.2 indicates, the sample $\mathrm{T} 6$, showed higher ascorbic content $(28.87 \mathrm{mg} / 100 \mathrm{~g})$ than other samples. The variation in ascorbic acid content may be due to liberation of ascorbic acid especially from the peel of the fruit, which is known to have 2.2 times more ascorbic acid than the flesh and the center [41] or the combined effect of treatment conditions [42].

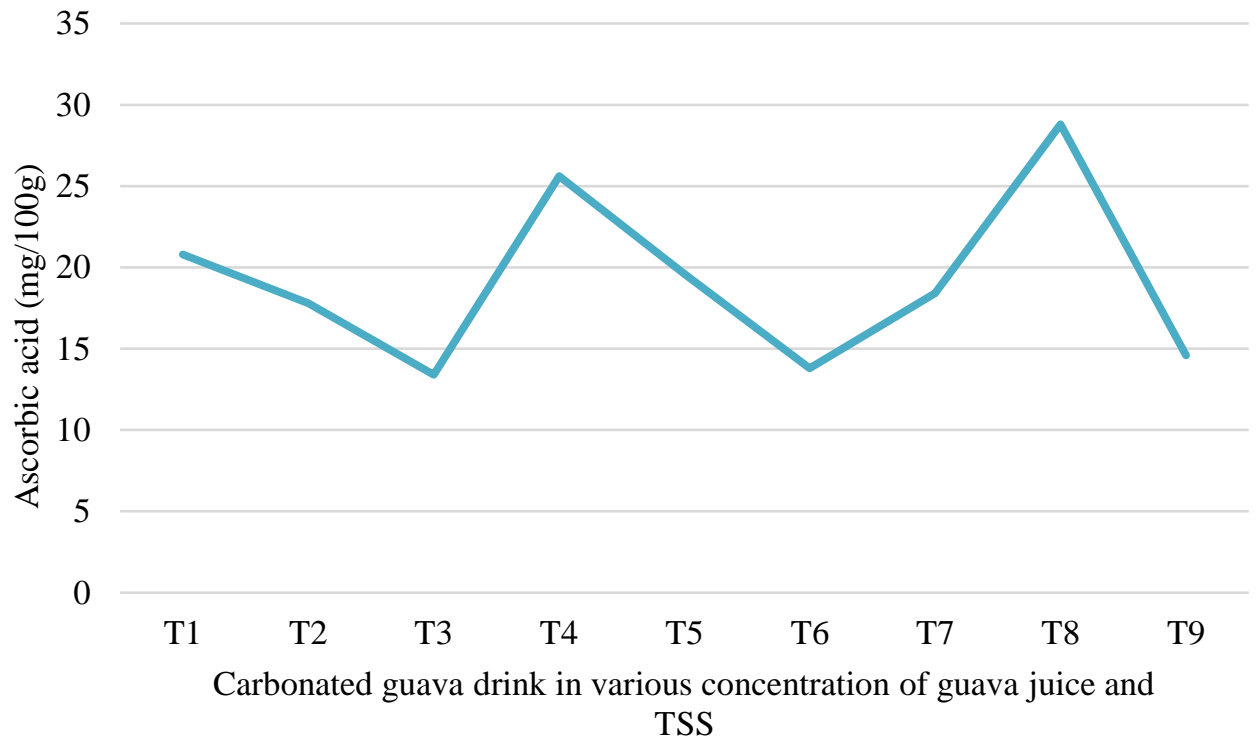

Figure 2: Ascorbic acid in carbonated guava drink with various concentrations of guava fruit juice and total soluble solid.

The observed result of physiochemical parameters were indicated that among the treatments the combination of guava juice level at $20 \%$ with $12^{\circ} \mathrm{Bx}$ (Sample T6) had received highest ascorbic acid $28.87 \mathrm{mg} / 100 \mathrm{~g}$, high color value $\Delta \mathrm{E} 4.60$, high acidity $0.51 \%$ and highest volume of $\mathrm{CO}_{2} 2.7 \%$. Similar study have been done in the carbonated beverage contains $25 \%$ guava fruit juice, $0.5 \%$ acidity and $20 \%$ TSS [43].

3.2. Effect of fruit juice concentration and its TSS in carbonated fruit drink on sensory attributes

Sensory evaluation is an important parameter to test the acceptability of the product by consumer. The sensory attributes of all the nine samples were evaluated by the 20 panelist to find out the best combination of guava juice and TSS concentration and the results were presented in the Table 3 .

Table 3: Sensory analysis of the carbonated guava fruit drinks

\begin{tabular}{|c|c|c|c|c|c|}
\hline \multirow{2}{*}{$\begin{array}{c}\text { Juice } \\
+ \\
\text { TSS Concent- } \\
\text { ration } \\
\end{array}$} & \multicolumn{5}{|c|}{ Sensory attributes } \\
\hline & Color & Flavor & Appearance & Taste & OAA \\
\hline $\mathrm{T} 1$ & $* 7.72 \pm 1.33^{b}$ & $* 8.30 \pm 0.97 \mathrm{ab}$ & $* 7.76 \pm 1.20$ ab & $* 7.10 \pm 1.02^{b}$ & $* 7.00 \pm 1.16^{c}$ \\
\hline $\mathrm{T} 2$ & $7.85 \pm 1.59^{b}$ & $7.55 \pm 1.82^{\mathrm{b}}$ & $7.85 \pm 1.72$ ab & $8.35 \pm 1.87^{a}$ & $8.05 \pm 1.31 \mathrm{ab}$ \\
\hline T3 & $6.95 \pm 1.88^{c}$ & $8.05 \pm 1.27 \mathrm{ab}$ & $7.65 \pm 1.72 \mathrm{ab}$ & $7.50 \pm 1.88 \mathrm{ab}$ & $7.95 \pm 1.14 \mathrm{~b}$ \\
\hline $\mathrm{T} 4$ & $7.68 \pm 0.93^{b}$ & $7.80 \pm 1.30^{b}$ & $8.06 \pm 1.09$ a & $7.18 \pm 1.37 \mathrm{~b}$ & $7.71 \pm 1.17^{b}$ \\
\hline $\mathrm{T} 5$ & $8.04 \pm 0.66$ ab & $7.45 \pm 0.94 \mathrm{~b}$ & $7.47 \pm 1.29 \mathrm{ab}$ & $7.80 \pm 1.36^{b}$ & $7.29 \pm 1.32 \mathrm{~b}$ \\
\hline T6 & $8.74 \pm 1.2^{\mathrm{a}}$ & $8.83 \pm 1.39$ a & $8.15 \pm 1.05 \mathrm{~b}^{\mathrm{a}}$ & $8.53 \pm 1.67$ a & $8.61 \pm 1.0^{\mathrm{a}}$ \\
\hline $\mathrm{T} 7$ & $7.95 \pm 0.75^{b}$ & $7.95 \pm 1.50^{\mathrm{b}}$ & $7.13 \pm 1.18^{b}$ & $7.19 \pm 1.74 \mathrm{~b}$ & $8.01 \pm 1.33 \mathrm{ab}$ \\
\hline $\mathrm{T} 8$ & $8.17 \pm 0.5 \mathrm{ab}$ & $8.09 \pm 1.31 \mathrm{ab}$ & $7.15 \pm 1.1^{\mathrm{b}}$ & $7.51 \pm 0.68^{\mathrm{ab}}$ & $7.69 \pm 0.59 \mathrm{~b}$ \\
\hline T9 & $8.03 \pm 0.75^{\mathrm{ab}}$ & $7.30 \pm 1.11^{\mathrm{b}}$ & $7.10 \pm 1.1^{b}$ & $7.0 \pm 0.5^{c}$ & $7.35 \pm 1.03^{b}$ \\
\hline
\end{tabular}

*Mean values \pm standard error mean (SEM). Values labeled with a different letter in the same column are significantly different ( $<<0.05), 0 A A: 0 v e r a l l$ acceptability. 
The result of table 2 revealed that there was slight change in color of samples. Highest percentage of carbon dioxide in the sample combination of guava juice at $20 \%$ with TSS at $12^{\circ} \mathrm{Bx}(\mathrm{T} 6)$ contributes better. This result was agreed with findings of Chilana et al. [44]. T3 scores lower than all the samples due to lower guava fruit juice and sugar concentration, which forced the panel members to rank lower. By comparing scores given by panel members it was clear that color of carbonated drinks depends on amount of guava juice and $\mathrm{CO}_{2}$ added to the drinks

The sample (T6) scored higher for flavor followed by eight other samples. Sample T9 was significantly inferior over all, because usage of higher proportion of guava fruit juice affects the flavor of the sample. Thus, increase in proportion of guava juice was not acceptable by the panel members due to its intense flavor.

Taste of the samples significantly changed with usage of different amount of fruit juice, sugar concentration and $\mathrm{CO}_{2}$. Higher levels of guava juice and sugar concentration and highest amount of $\mathrm{CO}_{2}$ significantly increased $(\mathrm{P}<0.05)$ the sensory attributes of taste $(8.53 \pm 1.67)$ and appearance $(8.15 \pm 1.05)$ in the sample T6.

Moreover, among the entire guava fruit drinks sample T6 containing 20 percent fruit juice reported the highest score in all the sensory quality attributes and found higher overall acceptability score $(8.61 \pm 1.0)$ which is highly preferred by the panelist among all the treatments. Sample T6 liked very much having moderate acidity content which will fulfil the taste and acceptability requirement for people serving the carbonated guava fruit drink. Additionally, it could also be seen that all the samples were found to be acceptable.

\subsection{Conclusion}

This research work was designed to formulate a carbonated guava fruit drinks by carbonation technique using new varieties of guava (BAARI Payera-4) fruit and also determined physico-chemical properties and sensory attributes. The changes in physicochemical characteristics were found in respect of different proportions of guava juices $(10 \%, 15 \%$, and $20 \%)$ and sugar concentrations $\left(10^{\circ}, 12^{\circ}\right.$ and $\left.15^{\circ} \mathrm{Brix}\right)$. By using guava juice at $20 \%$ with TSS at $12^{\circ} \mathrm{Bx}$ (Sample T6), the drink showed a decrease in viscosity, resulting in a better filtration process and high in acidity, TSS, color, total sugar and ascorbic acid as compared to that other samples. Also the organoleptic analysis showed that sample T6 was selected as the most preferred treatment based on organoleptic point of view. Thus the results from the present study indicates that the new varieties of guava (BAARI Payara-4) are suitable for preparing carbonated fruit drinks and can be used as a substitute for carbonated drinks.

\subsection{Acknowledgements}

The authors would like to express their sincere thanks to the Bangladesh Agriculture Research Institute (BARI), Gazipur, Bangladesh, for providing the guava variety, BAARI Peyara-4.

\subsection{References}

[1] S.A. Mulani, Tamboli, F.A., More, H.N., Kolekar, Y.S., and Mali, N. "Formulation and evaluation of medicated guava (Psidium guajava L.) wine using Saccharomyces crevices Var. HAU 1". Indian J Pharm Pharmacol, 8(2):168-170, 2021.

[2] P. Sahota, Kaur, D., Pandove, G. "Studies on the preparation of low alcoholic naturally carbonated blended beverage from guava and lemon". Int. J. Food Safety, 12:165-180, 2010.

[3] A. Akesowan, and Choonhahirun, A. "Effect of enzyme treatment on guava juice production using response surface methodology". Journal of Animal and Plant Sciences, 23(1): 114-120, 2013

[4] J.M. Omar, Nor, M.Z.M., Basri, M.S.M., and Che Pa, N.F. "Clarification of guava juice by an ultrafiltration process: analysis on the operating pressure, membrane fouling and juice qualities". Food Research 4 (Suppl. 1): 85-92, 2020.

[5] https://www.researchgate.net/publication/330663152.

[6] L. Harnack, Stang, J., Story, M. "Soft drink consumption among US children and adolescents: nutritional consequences". Journal of the American Dietetic Association.; 99(4):436-441, 1999. ISSN 0002-8223.

[7] M. Abid, et al. "Effect of ultrasound on different quality parameters of apple juice". Ultrasonics so no chemistry. 20(5):1182-1187, 2013. ISSN 13504177.

[8] V.S. Sandhan. "Preparation of carbonated beverage from pomegranate (Punica granatum L.) Fruits cv. Ganesh and Mridula". Mahatma Phule Krishi Vidyapeeth, Rahuri-413 722, Dist. Ahmednagar, Maharashtra, India, 2003.

[9] T. Calix, Ferrentino, G., Balaban, M. "Measurement of high-pressure carbon dioxide solubility in orange juice, apple juice, and model liquid foods". Journal of food science, 73(9), 2008. ISSN 1750-3841.

[10] D. Jori, Ladole, M., Gore, A., Bhand, V. "Study on Effect of Carbonation on Storage and Stability of Pineapple Fruit Juice". International Journal of Engineering Research \& Technology (IJERT) 2(12):1841-1847, 2013.

[11] M.F. Bertos, et al. "A review of accelerated carbonation technology in the treatment of cement-based materials and sequestration of $\mathrm{CO}_{2}$ ". Journal of hazardous materials, 112(3):193-205, 2004. ISSN 0304-3894.

[12] P. Leksrisompong, et al. "Descriptive Analysis of Carbonated Regular and Diet Lemon-Lime Beverages". Journal of Sensory Studies, 27(4):247-263, 2012. ISSN 1745-459X.

[13] N. Jain, Borkar, D. "Preparing beverage from guava”. Indian Horticulture.; 11:5-6, 1966.

[14] T. Ahmad, Senapati, A., Pandit, P. "Studies on Standardization of Nectar with Respective Pulp Percentage and Total Soluble Solids from Guava (Psidium guajava L.) cv. Lalit during Storage". International Journal, 1:17-21, 2015.

[15] S. Hossen, Kabir, M. S., Uddin, M. B., Rahman, A. K. M. L. and Mamun, M. R. A. "Effect of different extractions of juice on quality and acceptability of guava jelly". J. innov. dev. Strategy, 3(4): 27-35, 2009.

[16] N. Saba, Swamy, B. N., Nalini, B.S., Ashiwini, G. and Prasad, P. "Bioenrichment of Guava Juice with Prebiotic and Probiotics". International Journal of Current Microbiology and Applied Sciences. 7(7): 1307-1315, 2018.

[17] R. Hemalatha, Kumar, A., Prakash, O., Supriya, A., Chauhan, A. S., and Kudachikar, V. B. "Development and Quality Evaluation of Ready to Serve (RTS) Beverage from Cape Gooseberry (Physalis peruviana L.) MDPI Beverages". 4, 42, 2018. doi:10.3390/beverages4020042.

[18] S. Macdonald, Long, M., Gilbert, J., Felgueiras, I. "Liquid chromatographic method for determination of patulin in clear and cloudy apple juices and apple puree: collaborative study". Journal of AOAC International. 83(6):1387-1394, 2000.

[19] J. Lee, Durst, R.W., Wrolstad, R.E. "Determination of total monomeric anthocyanin pigment content of fruit juices, beverages", natural colorants, and wines by the $\mathrm{pH}$ differential method: collaborative study. Journal of AOAC international. 88(5):1269-1278, 2005.

[20] S. Ranganna. "Handbook of Analysis and Quality Control for Fruit and Vegetable products, Ranganna", S. (Ed.). Tata McGraw-Hill Publications, New Delhi. Pg 719-724, 2001.

[21] AOAC. "Official Method of Analysis". 18th ed. Association of Official Analytical Chemists, Maryland, USA, 2005.

[22] S. Ranganna. Handbook of analysis and quality control for fruit and vegetable products: Tata McGraw-Hill Education, 1986.

[23] A. Ganjloo, Rahman, R.A., Osman, A., Bakar, J., Bimakr, M. "Kinetics of crude peroxidase inactivation and color changes of thermally treated seedless guava (Psidium guajava L.)". Food and Bioprocess Technology. 4(8):1442-1449, 2011

[24] K.A. Chevaux, Jackson, L., Villar, M.E., Mundt, J.A., Commisso, J.F., Adamson, G.E. et al. "Proximate, mineral and procyanidin content of certain foods and beverages consumed by the Kuna Amerinds of Panama". Journal of food composition and analysis, 14(6):553-563, 2001.

[25] C. Thongrote, Wirjantoro, T., Phianmongkhol, A. "Effect of carbonation sources and its addition levels on carbonated mango juice". International Food Research Journal, 23(5), 2016

[26] I. Chakrabortya, and Athmaselvib, K.A. "Changes in Physicochemical Properties of Guava Juice during Ohmic Heating". Journal of Ready to Eat Food 1(4):152-157, 2014

[27] B.C. Deka, Sethi, V., Suneja, P., Srivastava, V.K. "Physico - chemical changes of lime-aonla spiced beverage during storage". Journal of Food Science and Technology, 41(31):329-332, 2004. 
[28] A. Sharma, Singh, K. "Effect of different treatments on TSS, sugars, viscosity and suspended pulp of lime juice during storage". Haryana Journal of Horticulture Science, 33(1-2):45-46, 2005.

[29] D. M. Kadam, Kaushik, P., Kumar, R. "Evaluation of Guava Products Quality". International Journal of Food Science and Nutrition Engineering, 2(1): 711, 2012. DOI: $10.5923 /$ j.food.20120201.02.

[30] D. Vignesh, Muthal, T., Chidanand, D.V., Sunil, C.K. "Study of Sensory and Storage Quality of the RTS Juice Enriched with Papaya Leaf Flavonoid", Ind. J. Pure App. Biosci. 7(4), 422-430, 2019. doi: http://dx.doi.org/10.18782/2320-7051.7662.

[31] R.B. Tiwari. "Studies on blending of guava and papaya pulp for RTS beverage". Indian Food Packer;; 54(2):68-72, 2000.

[32] M. Dhaliwal, Hira, K.C. "Effect of storage on physico-chemical and nutritional characteristics of carrot-beet root and carrot-black carrot juices". Journal of Food Science Technology, 38(4):343-347, 2001.

[33] R.P. Mane, Pawar, V.S., Kshirsagar, R.B. and Mohammad Nisar. "Studies on development of process technology for formulation, sensory evaluation and storage studies of fresh turmeric rhizome juice-based orange RTS beverage". International Journal of Chemical Studies; 7(1): 1704-1709, 2019.

[34] R.L. Bhardwaj, Mukherjee, J. "Effects of fruit juice blending ratios on kinnow juice preservation at ambient storage condition". African Journal of Food Science. 5(5), 281-286, 2011.

[35] C.A. Del, Piga, A., Vacca, V., Agabbio, M. "Changes of flavonoids, vitamin C and antioxidant capacity in minimally processed citrus segments and juices during storage". Food Chemistry, 84:99-105, 2004.

[36] A. Akesowan, and Choonhahirun, A. "Effect of enzyme treatment on guava juice production using response surface methodology". The Journal of Animal \& Plant Sciences, 23(1): 114-120. ISSN: 1018-7081, 2013.

[37] D.C. Pham, Vu, N.H., Samhaber, W., Nguyen, M.T. "Physicochemical Characteristics and Aroma Analysis of Passion Fruit Juice and Guava Juice Concentrated by a Novel Evaporation Concept", Chemical Engineering Transactions, 75, 43-48, 2019. DOI:10.3303/CET1975008.

[38] G. Sindhumati, Premalatha, M. "Development and Storage Studies of Naturally Flavored Papaya-Pineapple Blended Ready-to-Serve (RTS) Beverages". Int. J. Sci. Res., 4, 856-860, 2013

[39] H. Darvishi, Mohammad, H.K. and Najafi, G. "Ohmic heating of pomegranate juice: Electrical conductivity and pH change". Journal of the Saudi Society of Agricultural Sciences, 12: 101-108, 2013.

[40] J.E. Brekke, Cavaletto, C.G., Nakayama, T.O.M., Suehisa, R.H. "Effect of storage temperature and container lining on some quality attributes of papaya nectar". Journal of Agricultural and Food Chemistry. 24(2):341-343, 1976.

[41] M.C. Amoth. "The chemical analysis of sugars and acid of guava juice from variety grown in Kenya". MSc Thesis, University of Nairobi, 1980.

[42] K. Sawinder. "Optimization of enzymatic hydrolysis process parameters for maximum juice recovery from guava using response surface methodology". MTech Thesis, Punjab Technical University, Jalandhar, Punjab, India, 2007.

[43] N. Vasure, Patil, D., Dewangan, R. "Studies on Preparation and Preservation of Ginger Blended Pomegranate Ready to Serve Beverages". Annals of Plant and Soil Research, 87, 2016.

[44] H. Chilana, Arora, S., Khajuria, R., Kaur, L. "Non-Alcoholic, Naturally-Carbonated Beverage from Vitis Vinifera Using Saccharomyces Cerevisae Isolated from Cheese Whey". Online Journal of Biological Sciences. 15(3):184, 2015. 